\title{
UPAYA MENGEMBANGKAN BAHASA DALAM MENGENAL PEMBENDAHARAAN KATA MENGENAI KATA SIFAT MELALUI MODEL EXAMPLES NON EXAMPLES PADA KELOMPOK A TK AL-KHAIRIYAH MARTAPURA
}

\author{
Oleh: Siti Rahmah Amini \\ (Mahasiswa S1 PG PAUD Universitas lambung Mangkurat)
}

\begin{abstract}
Abstrak
Permasalahan dalam penelitian ini adalah rendahnya kemampuan anak meguasai keterampilan yang ditandai dengan rendahnya hasil pengembangan bahasa dalam mengungkapkan kata sifat. Hal ini disebabkan anak kurang aktif dalam kegiatan pembelajara, pembelajaran cenderung berpusat pada guru. Oleh sebab itu perlu menyusun kegiatan pembelajaran dengan menerapkan suatu model pembelajaran, melalui model pembelajaran examples non examples untuk membuat pembelajaran menjadi bermakna dan menyenangkan. Tujuan dari penelitian ini adalah untuk mengetahui aktivitas guru, meningkatkan aktivitas siswa, dan meningkatkan hasil pengembangan bahasa anak.

Penelitian ini menggunakan metode tindakan kelas, dengan rancangan 2 siklus 3 kali pertemuan. Setting penelitiannya di kelompok A TK Al-Khairiyah Martpaura. Instrument penelitian yang digunakan adalah lembar observasi aktivitas guru dan lembar observasi aktivitas siswa dan LKS evaluasi untuk siswa yang diadakan pada akhir pertemuan.

Hasil penelitian menunjukkan bahwa aktivitas guru, aktivitas siswa, dan hasil belajar pengembangan bahasa anak kelompok A TK Al Khairiyah Martapura mengalami peningkatan. Hal ini terlihat dari hasil observasi aktivitas guru yaitu mendapat skor 26 pada pertemuan 1, dan 27 pada pertemuan 2, sedangkan pada siklus II pertemuan 1 meningkat menjadi 28, sedangkan observasi aktivitas anak yaitu 79,44\% katagori aktif pada pertemuan 1 siklus I, dan 82,22\% katagori sangat aktif pada pertemuan 2, meningkat menjadi 93,33\% katagori sangat aktif pada pertemuan 1 siklus II begitu juga dengan hasil pengembangan anak yaitu $100 \%$ di atas indikator ketuntasan pengembangan pada pertemuan 1, menurun pada pertemuan 2 menjadi 73,33\% ketuntasan, kemudian meningkat pada siklus II menjadi 100\% di atas indikator ketuntasan yang telah ditetapkan.

Berdasarkan hasil temuan penelitian ini disarankan agar guru-guru di tamak kanak-kanak dapat menggunakan model Examplen non Examples dalam melaksanakan kegiatan pengembangan bahasa sebagai upaya dalam menciptakan perbaikan dan meningkatkan pemahaman anak, aktivitas anak serta meningkatkan mutu kualitas pembelajaran disekolah masing-masing.
\end{abstract}

Kata Kunci: Pengembangan bahasa, kata sifat, Model examples non examples

\section{A. Pendahuluan}

Bahasa memegang peran penting dalam kehidupan manusia karena bahwa merupakan alat komunikasi manusia dalam kehidupan sehari-hari. Dengan bahasa seseorang dapat menyampaikan ide, pikiran perasaan kepada orang lain, baik secara lisan maupun tulisan, hal ini sejalan dengan pendapat Depdiknas (2008 : 134), bahwa bahasa adalah sistem lambing bunyi berartikulasi yang bersifat sewenang-wenang dengan konversional yang 
dipakai sebagai alat komunikasi untuk melahirkan perasaan dan pikiran.

Anak usia dini, khususnya usia 4-5 tahun dapat mengembangkan kosa kata secara mengagumkan. Owens dalam Dhieni (2009 : 3) mengemukakan bahwa "Anak usia tersebut memperkaya kosa katanya mellaui pengulangan". Mereka sering mengulangi kosa kata yang baru dan unik sekalipun mungkin belum memahami artinya. Dalam mengembangkan kosa kata tersebut, anak menggunakan tast mopping yaitu suatu proses dimana anak menyerap arti kata baru setelah mendengarnya sekali atau dua kali dalam percakapan. Pada masa kanak-kanak awal inilah anak mulai mengkombinasikan suku kata menjadi kata dan kata menjadi kalimat.

Anak usia 4-5 gatun, rata-rata dapat menggunakan 900 sampai 1000 kosa kata yang berbeda. Mereka menggunakan 4-5 kata dalam satu kalimat yang dapat berbentuk kalimat pernyataan negatif, tanya dan perintah. Anak usia 4 tahun sudah mulai dapat menggunakan kalimat yang beralasan seperti "Saya menagis karena sakit" pada usia 5 tahun pembicangan mereka mulai berkembang dimana kosa kata yang digunakan lebih banyak dan rumit.

Penelitian membuktikan bahwa terdapat "Masa krisis" dalam perkembangan bicara dan bahasa pada bayi dan anak, sebagian ahli menyatakan bahwa masa krisis ini perkembangan otak bayi dan anak sedang mengalami kemampuan maksimal dalam menyerap bahasa kemampuan seorang anak dalam mempelajari bahasa akan lebih sulit, dan mungkin kurang efesuen dan efektif, jika masa kritis ini dibiarkan lewat begitu saja tanpa memperkenalkannya pada bahasa.

Hal ini sesuai dengan yang dikaitkan oleh Bwnen (Dhieni, 2009 : 6.28) berkenan dengan perkembangan pikiran anak yang dikaitkan dengan perkembangan bahasa anak ialah "Anak memahami dunia sekitarnya dengan tiga tingkatan modus perwakilan pemikiran, yaitu tiga cara pemikiran yang menggambarkan (dalam arti memahami) pengertian tentang objek-objek yang diamati didunia sekitar. Dengan demikian kegiatan mengungkapkan kata-kata yang berarti/bermakna sangat membantu perkembangan bahasa anak maupun perkembangan berpikir anak, diantyaranya adalah kognitif, emosional dan kreatifitas anak.

Kondisi objektif yang terjadi di TK AlKhairiyah Martapura Kabupaten Banjar saat kegiatan pembelajaran pengembangan kemampuan bahasa adalah cenderung berpusat pada guru dan tidak menggunakan media pembelajara. Guru hanya menggunakan metode ceramah terhadap anak, sehingga interkasi bercakap-cakap antara guru dan anak jarang sekali dilakukan. Guru juga kurang memberikan kesempatan kepada anak untuk mengungkapkan gagasan sesuai minatnya. Sebagian anak hanya duduk diam mendengarkan penjelasan dari guru, sedangkan 
anak lainnya ada yang bercanda dengan temantemannya tanpa memperhatikan pembelajaran yang disampaikan oleh guru.

\section{B. Kajian Teori}

\section{Pengertian Anak Usia Dini}

"Pendidikan anak usia dini adalah suatu upaya pembinaan yang ditujukan kepada anak sejak lahir sampai dengan usia enam tahun yang dilakukan melalui pemberian rangsangan pendidikan untuk membantu pertumbuhan dan perkembangan jasmani dan rohani agar anak memiliki kesiapan dalam memasuki pendidikan yang lebih lanjut" (UU NO. 20. Tahun 2003 Tentang Sisdiknas). Hal ini membuktikan bahwa pendidikan sejak usia dini sangat penting untuk memberikan rangsangan dalam belajar pada anak sehingga anak mempunyai pertumbuhan dan perkembangan yang lebih baik untuk masa depannya.

Sementara itu National Association for the Education of Young Children (NAEYC) (Santoso, 2009: 1. 3) membagi anak usia dini menjadi 0-3 tahun. 3-5 tahun, dan 6-8 tahun. Feld \& Baur (Santoso, 2009: 1.3) membagi anak usia dini menjadi lahir sampai 1 tahun (bayi-infancy), 1-3 tahun (fodder). 3-4 tahun (prasekolah), 5-6 tahun (kelas awal /SD), dan 7-8 tahun (kelas lanjut SD).

Bloom (1964) dalam (Santoso, 2009: 1.3) menyatakan bahwa "'pendidikan sejak usia dini penting sekali sebab perkembangan emntal yang meliputi perkembangan inteligensi, kepribadian dan tingkah laku sosial berlangsung cepat, pada usia dini. Menurut Landshcars (1979) dalam (Santoso, 200: 1.3) “perkembangan kognitif pada anak usia dini 48 tahun. Dengan demikian, pendidikan bagi anak usia dini 4-8 tahun sudah mencapai 30\%."

\section{Perkembangan Bahasa Anak Usia Taman Kanak-Kanak.}

Perkembangan bahasa anak dapat kita lihat dari keterampilannya dalam berbahasa. Menurut Tarigan dalam Satata (2009; Online) keterampilan berbahasa (language arts, language skills) dalam kurikulum di sekolah biasanya mencakup empat segi, yaitu :

1) Keterampilan menyimak/ mendengarkan (listening skills).

2) Keterampilan berbicara (speaking skills)

3) Keterampilan membaca (reading skills)

4) Keterampilan menulis (writing skills).

Keempat keterampilan tersebut sangat erat hubungannya satu dengan yang lain, dengan stimulasi yang sesuai maka keempat keterampilan tersebut dapat dilewati dengan baik. Dalam mendapatkan terampilan berbahasa ini dilalui secara teratur, diawali ketika kita masih kecil dengan belajar mendengarkan dan belajar berbicara. Setelah mulai berkembang dan kita mulai memasuki Taman Kanak-kanak kita akan distimulasi agar sensori motor kita dapat terlatih untuk mulai dapat membaca dan menulis sebagai bekal untuk memasuki tahap Sekolah Dasar. 
Menurut Jamaris, (2005:32) Karakteristik perkembangan kemampuan bahasa anak usia empat tahun diantaranya :

a. Terjadi perkembangan yang cepat dalam kemampuan bahasa anak. Ia telah dapat menggunakan kalimat yang baik dan benar.

b. Telah menguasai $90 \%$ dari fonem dan sintaksis bahasa yang digunakannya.

c. Dapat berpartisipasi dalam suatu percakapan. Anak sudah dapat mendengarkan orang lain berbicara dan menanggapi pembicaraan tersebut.

Kemampuan bahasa merupakan salah satu bidang perkembangan kemampuan dasar dalam kompetensi dasar pendidikan anak usia dini, dimana pengembangan kemampuan ini bertjuan agar anak mampu mengungkapkan pikiran melalui bahasa yang sederhana secara tepat, mampu berkomunikasi secara efektif dan membangkitkan minat untuk bahasa Indonesia.

\section{Model Pembelajaran Kooperatif}

"Model pembelajaran kooperatif merupakan suatu bentuk pengajaran yang dilaksanakan dalam kelompok-kelompok kecil dengan tingkat kemampuan anak bervarias “ (Rahmadiarti, 2003: 21). Pada model ini anak berkelompok untuk menyelesaikan suatu masalah, setiap anggota saling kerjasama dan membantu untuk memahami suatu bahan ajar. Anak yang bekerja sama pada suatu tugas bersama, dan mereka harus mengkoordinasikan usahanya untuk menyelesaikan tugasnya.
Pembelajaran kooperatif merupakan suatu model pembelajaran dimana anak belajar dalam kelompok-kelompok kecil yang memiliki tingkat kemampuan yang berbeda. Dalam menyelesaikan tugas kelompok, setiap anggota saling bekerja sama dan membantu untuk memahami suatu bahan pembelajaran. Model pembelajaran kooperatif dapat memberi keuntungan baik bagi anak kelompok bawah maupun kelompok atas yang bekerja bersama dalam menyelesaikan tugas-tugas akademik.

Ibrahim (2000:21) menyatakan bahwa "Pembelajaran kooperatif dicirikan oleh struktur tugas, tujuan dan pengalaman kooperatif”. Anak yang bekerja dalam situasi pembelajaran kooperatif didorong atau dikehendaki untuk bekerjasama pada suatu tugas bersama, dan anak harus mengkoordinasikan usahanya untuk menyelesaikan tugasnya. Dalam penerapan model pembelajaran kooperatif, dua atau lebih individu saling tergantung satu sama lain untuk mencapai satu penghargaan bersama. Kelompok anak akan berbagi penghargaan seandainya berhasil dalam memecahkan masalah yang diajarkan kepada kelompok pembelajaran.

Melalui belajar secara kelompok, diharapkan dapat ditumbuhkembangkan rasa sosial yang tinggi pada diri setiap anak. Mereka dibina untuk mengendalikan rasa egois yang ada dalam diri mereka masing-masing, sehingga terbina sikap kesetiakawanan sosial di kelas. 
Anak dibiasakan hidup bersama, bekerja sama dalam kelompok, akan menyadari bahwa dirinya mempunyai kekurangan dan kelebihan. Anak yang mempunyai kelebihan dengan ikhlas mau membantu anak yang mempunyai kekurangan. Sebaliknya, anak yang mempunyai kekurangan dengan rela hati mau belajar dari anak yang mempunyai kelebihan, tanpa ada rasa minder. Persaingan yang positif pun akan terjadi di dalam kelas dengan tujuan untuk mencapai prestasi yang optimal. Inilah yang diharafkan dalam pembelajaran kelompok, yaitu terbentuk anak yang aktif, kreatif, dan mandiri.

\section{Model Pembelajaran Kooperatif Examples non Examples}

Secara kaffah model dimaknakan sebagai suatu objek atau konsep yang digunakan untuk merepresentasikan sesuatu hal. Sesuatu yang nyata dan dikonversi untuk sebuah bentuk yang lebih komprehensif (Trianto, 2010: 21).

Menurut Suriansyah (2009: 19) model merupakan "suatu pola yang dapat digunakan untuk merancang bahan pembelajaran dan melaksanakan pembelajaran".

Salah satu model pembelajaran kooperatif yang menjadi bahan Penelitian Tindakan Kelas (PTK) adalah Salah satu model alternatif yang akan digunakan untuk masalah diatas peneliti menggunakan model examples non examples. Examples Non Examples adalah metode belajar yang menggunakan contoh-contoh. Contoh- contoh dapat dari kasus atau gambar yang relevan dengan kompetensi dasar.

Model pembelajaran examples non examples membelajarkan kepekaan siswa terhadap permasalahan yang ada di sekitarnya melalui analisis contoh-contoh berupa gambargambar/foto/kasus yang bermuatan masalah. Siwa diarahkan untuk mengidentifikasi masalah, mencari alternative pemecahan masalah dan menentukan cara pemecahan masalah yang paling efektif, serta melakukan tindak lanjut (Komalasari, 2010: 61).

Model pembelajaran pada dasarnya merupakan bentuk pembelajaran yang tergambar dari awal sampai akhir yang disajikan secara khusus oleh guru. Dengan kata lain, model pembelajaran merupakan bungkus atau bingkai dari penerapan suatu pendekatan, metode, dan teknik pembelajaran (Sudrajat,2008: 3).

Adapun langkah-langkahnya adalah :

a. Guru mempersiapkan gambar-gambar sesuai dengan tujuan pembelajaran.

b. Guru menempelkan gambar di papan atau ditayangkan lewat OHP.

c. Guru memberi petunjuk dan memberi kesempatan kepada siswa untuk menganalisa atau memperhatikan gambar.

d. Melalui diskusi kelompok 3-4 orang siswa, hasil diskusi dari analisa gambar tersebut dicatat pada kertas.

e. Tiap kelompok diberi kesempatan untuk membacakan hasil diskusinya. 
f. Mulai dari komentar / hasil diskusi siswa, guru mulai menjelaskan materi sesuai tujuan yang ingin dicapai.

g. Guru dan peserta didik menyimpulkan materi sesuai tujuan pembelajaran.

(Kusuma, W. 2008) menyatakan kelebihan model pembelajaran examples non examples adalah sebagai berikut :

a. Siswa lebih kritis dalam menganalisa gambar.

b. Siswa mengetahui aplikasi dari materi berupa contoh gambar.

c. Siswa diberikan kesempatan untuk mengemukakan pendapatnya.

\section{Metodologi Penelitian}

\section{Pendekatan dan Jeis Penelitian}

Pendekatan penelitian tindakan yang digunakan dalam penelitian ini adalah pendekatan kualitatif.

Metode tindakan kelas yang digunakan dalam penelitian ini adalah bentuk pembelajaran yang bersifat reflektif untuk memperbaiki kondisi pembelajaran dan meningkatkan kemantapan rasional dari tindakan melaksanakan tugas dengan proses pengkajian berdaur, yaitu (1) perencanaan, (2) pelaksanaan, (3) observasi dan mengevaluasi dan (4) refleksi hasil tindakan dari berbagai kegiatan pembelajaran (Arikunto, 2010:16).

Jenis penelitian yang dilakukan adalah Penelitian Tindakan Kelas (PTK). Penelitian tindakan kelas adalah "sebuah penelitian yang dilakukan oleh guru dikelasnya sendiri dengan jalan merancang, melaksanakan dan merefleksikan kinerjanya sebagai guru sehingga hasil belajar anak dapat meningkat" (Anurrahman, 2009:1.1).

\section{Setting Penelitian}

Lokasi/tempat penelitian dilaksanakan di TK. AL-KHAIRIYAH MARTAPURA. Subjek penelitian ini adalah anak didik pada kelompok A TK. AL-KHAIRIYAH MARTAPURA dengan jumlah 15 anak yang terdiri dari 4 anak laki-laki dan 11 anak perempuan. Penelitian dilaksanakan pada bulan November 2014 Semester I (satu) Tahun ajaran 2014-2015.

\section{Skenario Tindakan}

Penelitian ini merupakan penelitian tindakan kelas (PTK). Prosedur penelitian tindakan kelas ini terdiri dari 2 siklus.

\section{Data dan Cara Pengambilan Data}

\section{a) Sumber Data}

Sumber data dalam penelitian ini adalah anak TK. AL-KHAIRIYAH MARTAPURA pada semester ganjil tahun pelajaran 2014/2015 yang berjumlah 15 anak.

\section{b) Cara Pengambilan Data}

Kemampuan bahasa anak, yaitu mengamati kemampuan bahasa anak dalam mengurutkan dan menceritakan gambar seri dengan urut dan bahasa yang jelas.

\section{Hasil Penelitian}

Pelaksanaan Tindakan Kelas Siklus I

\section{Pertemuan I}


Hasil Observasi Pengembangan Bahasa Anak

Berikut ini merupakan data hasil pengembangan anak yang selama mengikuti proses pembelajaran dengan model examples non examples serta pada siklus I pertemuan $1 \mathrm{di}$ kelompok A TK Al- Khairiyah Martapura:

Tabel Hasil Belajar Anak Siklus I pertemuan 1

\begin{tabular}{|c|c|c|}
\hline Nilai & \multicolumn{2}{|c|}{ Bahasa } \\
\hline & $\mathrm{F}$ & $\%$ \\
\hline $0 \theta 0 \theta$ & 8 & 53,33 \\
\hline$\theta 0 \theta$ & 7 & 46,47 \\
\hline$\theta 0$ & 0 & 0 \\
\hline$\theta$ & 0 & 0 \\
\hline $\mathrm{Jmh}$ & 15 & 100 \\
\hline
\end{tabular}

Hal ini dikarenakan anak memahami dan mengerti untuk menghubungkan gambar dan kata yang sesuai. Mereka semua mendengarkan penjelasan dari gurunya, walaupun masih banyak anak yang dibimbing dalam mengerjakannya namun mereka semua dapat dengan tepat menghubungkannya.

\section{Refleksi}

Refleksi terhadap kegiatan pembelajaran pada siklus I pertemuan 1 adalah sebagai berikut:

Hasil pengembangan bahasa anak pada pertemuan 1 anak yang mendapatkan bintang 4 (****) ada 8 orang anak dan yang mendapatkan perolehan bintang 3 (***) ada 7 orang anak. Semua anak sudah berada dalam katagori berkembang sangat baik (BSB) dan berkembang sesuai harapan (BSH), walaupun demikian agar hasil pengembangan anak keseluruhan mendapatkan bintang $4(* * *)$ guru perlu memberikan bimbingan dan arahan yang lebih maksimal agar hasil pengembangan bahasa pada pertemuan berikutnya meningkat.

Pelaksanaan Tindakan Kelas Siklus I

\section{Pertemuan II}

\section{Hasil Observasi Pengembangan Bahasa Anak}

Berikut ini merupakan data hasil pengembangan anak selama mengikuti proses pembelajaran dengan model examples non examples pada siklus I pertemuan 2 di kelompok B TK Al-Khairiyah Martapura..

Tabel Hasil Belajar Siswa Siklus I Pertemuan 2

\begin{tabular}{|l|l|l|}
\hline Nilai & \multicolumn{2}{|l|}{ Bahasa } \\
\hline & F & $\%$ \\
\hline \multirow{0}{0}{} & 0 & 0 \\
\hline $\mathbf{0}$ & 11 & 73,33 \\
\hline Jmh & 3 & 20 \\
\hline
\end{tabular}

\section{Refleksi}

Refleksi terhadap kegiatan pembelajaran pada siklus I pertemuan 2 adalah sebagai berikut:

Hasil pengembangan bahasa anak pada pertemuan 2 anak yang mendapatkan bintang 3 (***) ada 11 orang anak dengan katagori 
berkembang sesuai harapan dan yang mendapatkan bintang 2 (**) ada 3 orang anak dengan katagori mulai berkembang dan bintang 1 (*) ada 1 orang anak dengan katagori belum berkembang. Hal ini dikarenakan masih ada anak yang belum memahami materi mengenal pembendaharaan kata mengenai kata sifat. Oleh karena itu, diperlukan perbaikan pada saat menjelaskan dan memberikan bimbingan, arahan pada anak agar hasil pengembangan pada pertemuan berikutnya meningkat.

\section{Pelaksanaan Tindakan Kelas Siklus II Pertemuan I}

\section{Hasil Observasi Pengembangan Bahasa Anak}

Hasil pengembangan bahasa anak pada siklus II pertemuan 1 dapat dilihat pada tabel berikut:

Tabel Hasil Pengembangan Anak Siklus II Pertemuan 1

\begin{tabular}{|l|l|l|}
\hline Nilai & \multicolumn{2}{|l|}{ Bahasa } \\
\hline & F & $\%$ \\
\hline & 8 & 53,33 \\
\hline \multirow{2}{*}{} & 7 & 46,47 \\
\hline Jmh & 0 & 0 \\
\hline & 0 & 0 \\
\hline
\end{tabular}

\section{Refleksi}

Refleksi terhadap kegiatan pembelajaran pada siklus II pertemuan 1 adalah sebagai berikut: Hasil pengembangan anak pada siklus II pertemuan 1 anak yang mendapatkan bintang 3 (***) ada 7 orang dan bintang $4(* * * *)$ ada 8 orang anak, tidak ada lagi anak yang mendapatkan nilai dibawah bintang 3 (***), hal ini sudah memenuhi indikator yang ditetapkan. Oleh karena itu, melihat dari hasil pengembangan anak yang sudah mencapai $100 \%$ ketuntasan maka penelitian ini tidak perlu dilanjutkan pada pertemuan 2 siklus II.

Berdasarkan temuan tersebut, maka dapat disimpulkan bahwa adanya peningkatan di setiap pertemuannya baik itu aktivitas guru, aktivitas anak dan hasil pengembangan bahasa, maka kegiatan PTK pada pertemuan pertama ini sudah berhasil.

\section{Pembahasan}

Hasil Pembahasan kegiatan penelitian yang dilakukan oleh peneliti terhadap hasil perekembangan anak dalam mengenal pembendaharaan kata mengenai kata sifat melalui model Examples Non Examples Pada Kelompok A TK Al-Khairiyah Martapura Kabupaten Banjar adalah sebagai berikut :

Berdasarkan hasil pengamatan penilaian yang dilakukan terhadap hasil belajar anak / hasil perkembangan anak pada siklus I dan siklus II diperoleh data ketuntasan klasikal, dapat dievaluasi bahwa perkembangan bahasa anak berkembang sangat baik sekali. 
Hal tersebut sejalan dengan teori hasil belajar menurut Hamalik (2011:159) bahwa hasil belajar menunjukan kepada preestasi belajar, seangka prestos belajar itu merupakan indiator hanya derajat perubahan tingkah laku siswa.

Menurut Dimyati dan Mudjiono (2002:36) hasil belajar adalah hasil yang ditunjukan dari suatu interaksi tindak belajar dan biasanya ditunjukan dengan nilai tes yang diberikan guru. 


\section{DAFTAR PUSTAKA}

Agustiningrum. D. 2012. Penggunaan Media Gambar Seri untuk Mengembangkan Kemampuan Bercerita bagi Anak Taman Kanak-kanak di TK. PGRI Buah dua.Skripsi tidak diterbitkan, Bandung: PGPAUD. UPI.

Aminah, A. 2009. Penerapan Metode Bercerita (story telling) untuk Meningkatkan Keterampilan Menyimak dalam Pembelajaran Bahasa Inggris. Skripsi tidak diterbitkan, Bandung: FIPUPI.

Anurrahman, dkk. 2009. Penelitian Pendidikan SD. Jakarta: Depdiknas.

Arikunto, S. 2010a. Prosedur Penelitian Suatu Pendekatan Praktek. Jakarta : Rineka Cipta.

Arikunto, S. 2010b. Manajemen Penelitian. Jakarta : Rineka Cipta.

Arikunto, S. 2011. Penelitian Tindakan Kelas. Jakarta : Rineka Cipta.

Danaviah. I. 2010. Penggunaan Metode Bercerita Melalui Media Gambar Seri Untuk Meningkatkan Kemampuan Berbahasa Anak TK. Kelompok B. Di TK. Dharma Wanita 01 Binangan Kabupaten Blitar, Skripsi, Jurusan Kependidikan Sekolah Dasar Prasekolah. Skripsi tidak diterbitkan. FKIP. UNM.

Depdiknas. 2000a. Garis-garis Besar Program Kegiatan Belajar di TK. Jakarta : Universitas Terbuka.

Depdiknas , 2000b. 2008. Kamus Bahasa Indonesia. Jakarta : Pusat Bahasa.

Dhieni, N. Dkk. 2009. Metode Pengembangan Bahasa. Jakarta. Universitas Terbuka.

Harliyani, D. 2009. Hubungan Antara Kemampuan Guru dalam Bercerita dengan Kemampuan Anak dalam Menyimak Cerita. Skripsi tidak diterbitkan. Bandung: PGPAUD. FIP UPI.

Ibrahim, M. 2000. Pembelajaran Kooperatif. Surabaya. Pusat Sains dan Matematika Sekolah Program Pasca Sarjana Unesa. Universitas Press.

Isjoni. 2011. Cooperative Learning. Bandung : Alfabeta.

Jamaris, Martini. 2005. Perkembangan dan Pengembangan Anak Usia Taman Kanak-kanak. Jakarta : Grasindo.

Kemendiknas. 2010a. Pedoman Pengembangan Program Pembelajaran di TK. Jakarta : Direktorat Pembinaan TK dan SD.

Kemendiknas. 2010b. Pedoman Penilaian di TK. Jakarta : Direktorat Pembinaan TK dan SD. 
Kemendiknas. 2010c. Pedoman Pengembangan Silabus di TK. Jakarta : Direktorat Pembinaan TK dan SD.

Kumandar, 2008. Penelitian Tindakan Kelas. Jakarta : Raja Grafiindo Persada.

Masitoh, dkk. 2011. Strategi Pembelajaran TK. Jakarta. Universitas Terbuka.

Moeslichatoen, R. 2004. Metode Pengajaran di Taman Kanak-kanak. Jakarta : Rineka Cipta.

Mulyasa, 2010. Praktik Penelitian Tindakan Kelas. Bandung : PT. Remaja Rosda Karya.

Permendiknas No. 58 Tahun 2009 tanggal 17 September 2009 tentang Standar PAUD 2009. Jakarta : Fokusmedia.

Rachmadiarti, F. 2003. Pelatihan Terintegrasi Berbasis Kompetensi Guru Mata Pelajaran Sains IPA. Jakarta, Pembelajaran Kooperatif. Direktorat Jenderal Pendidikan Lanjutan Pertama Departemen Pendidikan Nasional.

Rupi'ati. 2011. Penggunaan Media Gambar Seri untuk Meningkatkan Kemampuan Bercerita Anak Kelompok B TK. Theobroma Kecamatan Kejayan Kabupaten Pasuruan. Skripsi tidak diterbitkan. Malang: PGPAUD. UNM.

Santoso, S. 2009. Dasar-dasar Pendidikan TK. Jakarta: Universitas Terbuka.

Satata, S. 2009. Aspek-aspek Keterampilan Berbahasa (Online). (http://pksm.mercubuana.ac.id/new/elearning/files_modul/99009-632707.doc., diakses 30 Maret 2012.)

Susilo, 2009. Panduan Penelitian Tindakan Kelas. Yogyakarta: Pustaka Book Publisher.

Sudjana S., D 2002. Metode \& Teknik Pembelajaran Partisipasif. Bandung : Falah Production.

Tim Instruktur. 2010. Modul Model Pembelajaran. Banjarmasin ; LPTK Rayon 17.

UU RI. No. 20 Tahun 2003. Undang-undang Sistem Pendidikan Nasional. Jakarta: PT. Intan.

Wartini. R. 2009. Peningkatan Keterampilan Berbicara Bahasa Sunda di Taman Kanak-kanak Melalui Metode Bercerita (Ngadongeng). Skripsi tidak diterbitkan. Bandung: PGPAUD UPI FIP.

Yusuf, S. 2001. Psikolgi Perkembangan Anak dan Remaja. Banung : PT. Remaja Rosda Karya. 